\title{
The Use of Digital Elevation Models (DEMs) for Bathymetry Development in Large Tropical Reservoirs
}

\author{
José de Anda* et al.** \\ Centro de Investigación y Asistencia en Tecnología y Diseño del Estado de \\ Jalisco, A.C. Normalistas 800, Guadalajara, Jalisco \\ México
}

\section{Introduction}

Bathymetry is the study of underwater depth of lake or ocean floors. In other words, bathymetry is the underwater equivalent to hypsometry (Miller et al., 2010), and this can be used also to describe the shape and volume of water reservoirs (Obregon et al., 2011). The bathymetry is generally obtained by recording water depths throughout a water body and connecting the recorded points of equal water depth. Hence, a bathymetric map is estimated from the water depth between two points of a known depth. There may be discrepancies in any given map depending on the number of depth measurements taken: the more depth measurements recorded, the more accurate the map is.

Important qualities such as the storage-capacity curve are derived from the bathymetry and it is also crucial to understand how a system functions, including surface area, maximum length, mean width, maximum width, mean depth, maximum depth, shoreline length and volume. The amount of detail in a bathymetry dataset depends on the resolution of the mapping system, its spatial accuracy, the amount of time and effort expended in making it, as well as consideration of its intended use (Ceyhun \& Yalçın, 2010).

Most of large reservoirs are formed by a dam across the course of a river, with subsequent inundation of the upstream land surface (Xu et al., 2011). The bathymetric shape of the reservoir basin coupled with the design and operation of the dam are critical to correctly modeling water quality. The combination of climate, reservoir bathymetry, seasonal hydrology, water chemistry, local wind, and temperature are all critical to modeling a

\footnotetext{
* Corresponding Author

** Jesus Gabriel Rangel-Peraza1, Oliver Obregon², James Nelson², Gustavious P. Williams²,

Yazmín Jarquín-Javier ${ }^{1}$, Jerry Miller ${ }^{3}$ and Michael Rode ${ }^{4}$

${ }^{1}$ Centro de Investigación y Asistencia en Tecnología y Diseño del Estado de Jalisco, A.C. Normalistas 800,

Guadalajara, Jalisco México

${ }^{2}$ Brigham Young University, Provo, Utah, USA

${ }^{3}$ Retired Water Quality Scientist, USA

${ }^{4}$ UFZ-Helmholtz Centre for Environmental Research, Department of Hydrological Modelling. Buckstrasse 3,

Magdeburg, Germany
} 
reservoir sufficiently correctly to test various dam designs or operational scenarios (Manivanan, 2008). The description of the water body in the bathymetry must be correct enough to simulate the reservoir hydrodynamics. Significant errors in the bathymetric description of the water body may prevent basic hydrodynamic calibration of the model. Reservoir bathymetric characteristics are, therefore, the starting point for water quality modeling (Zhao et al., 2011).

Just because a reservoir was once dry land, the bathymetry of this type of waterbody can be relatively easier to develop than lakes; this is due to the area capacity curve and topographic data developed in planning to build a dam. However, if the reservoir is old enough to have collected significant sediment deposition then additional sonar cross-section data may still have to be collected as in a natural lake.

The main scope of this work is to develop the bathymetry of Aguamilpa reservoir using spatial information in order to generate a tool that explains the elevation-capacity relationship for one of the largest tropical reservoirs in the world located in the western part of Mexico. Reliable storage capacity data for all water uses in the reservoir and useful information for current and future water quality assessments are provided with the development of this important tool.

\section{Study area}

The Aguamilpa reservoir is located in the central region of the state of Nayarit, Mexico and covers parts of the municipalities of Nayar, La Yesca, Santa Maria del Oro and Tepic. The Aguamilpa concrete-faced rockfill dam with $187 \mathrm{~m}$ high is one of the highest on its type in the world (Rangel-Peraza et al., 2009; Ibarra-Montoya et al., 2010). The main water contributions to the reservoir come from the Santiago and Huaynamota rivers. The reservoir is approximately $60 \mathrm{~km}$ long following the Santiago river course and $20 \mathrm{~km}$ along the Huaynamota River, covering a $109 \mathrm{~km}^{2}$ area.

The morphometric and morphological features of Aguamilpa reservoir are the result of the confluence of the Sierra Madre Occidental and Neovolcanic axis, two of the largest and most important mountainous systems in Mexico. A strike-slip fault, whose trace is now occupied by the Santiago River, produces extension and subsidence in the upper basin, while in the lower basin produces compression and uplift (INEGI, 2005).

The Aguamilpa hydroelectric dam is located inside of Santiago-Aguamilpa basin in the southwestern part of the Sierra Madre Occidental (Figure 1). This area is characterized by extrusive volcanic rocks (rhyolite-acid tuff) from the Miocene, intruded by dykes of various origins (Figures 2 and 3).

Extrusive volcanic rocks have been classified into 3 units: the lower is the Aguamilpa unit, the intermediate is named Colorines unit, and the highest is Picachos unit; the first consists of mass ignimbrite while the other two have pseudo stratification according to the Federal Electricity Commission (CFE, 1997).

The main geological structural features identified at the site, correspond to six faults oriented NE-SW, known as Colorines system. Four of these faults are located on the right bank and affect the generation works. The other two are located on the left and one of them 
involves the detour work and spillway. There are also four major fractures which show greater horizontal than vertical continuity (Mendes, 1995).

Like any other concrete-faced rockfill dam, Aguamilpa reservoir required a footing (or plinth) to be constructed around its upstream edge. The plinth, located in the Aguamilpa unit, was made from concrete and serves as a connection between the dam and the valley walls and floor. On the other hand, water intake and excess discharge (spillway) structures were excavated in Colorines and Picachos units, respectively (Mendes, 2005).

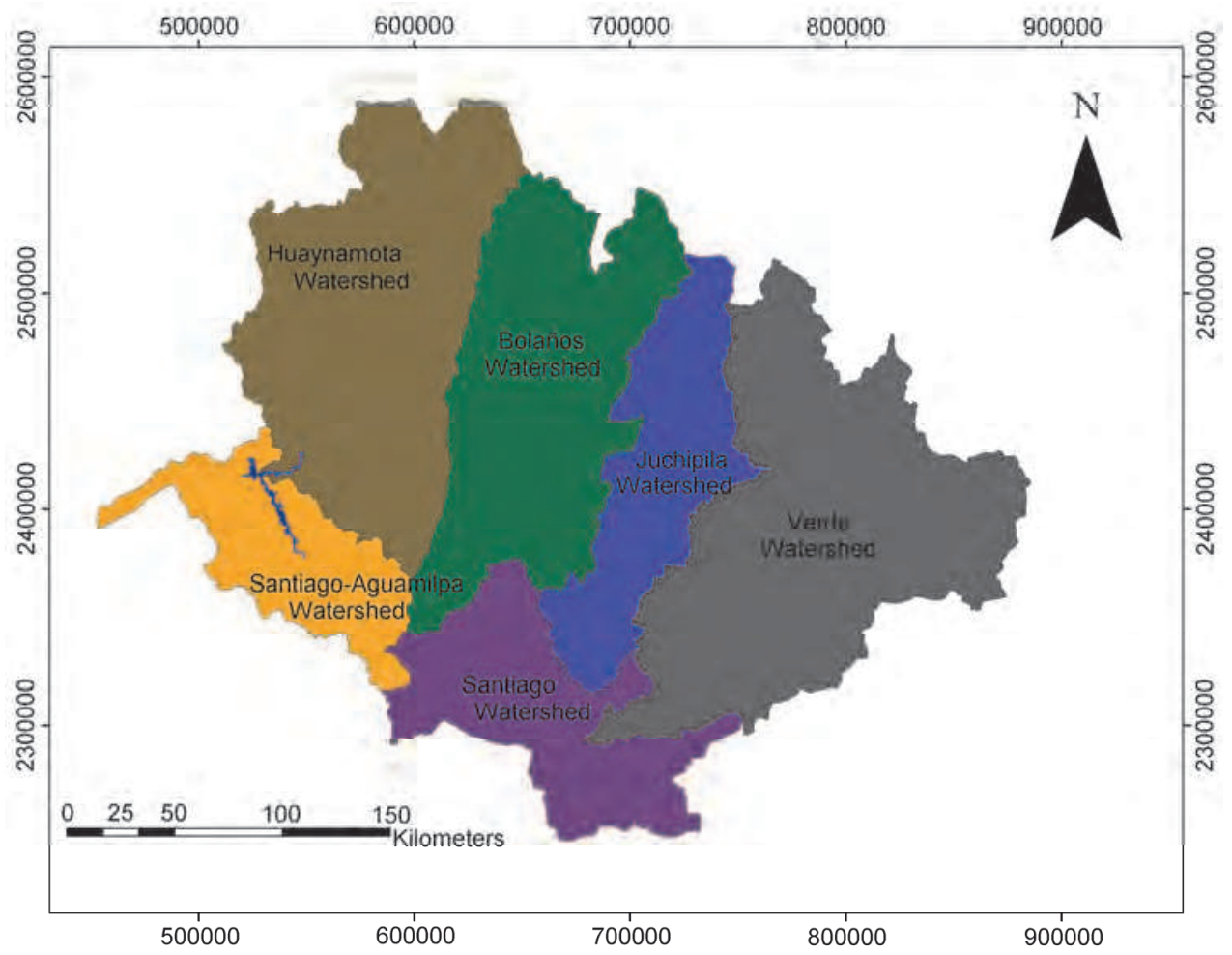

Fig. 1. Aguamilpa reservoir location in the Santiago-Aguamilpa watershed. 


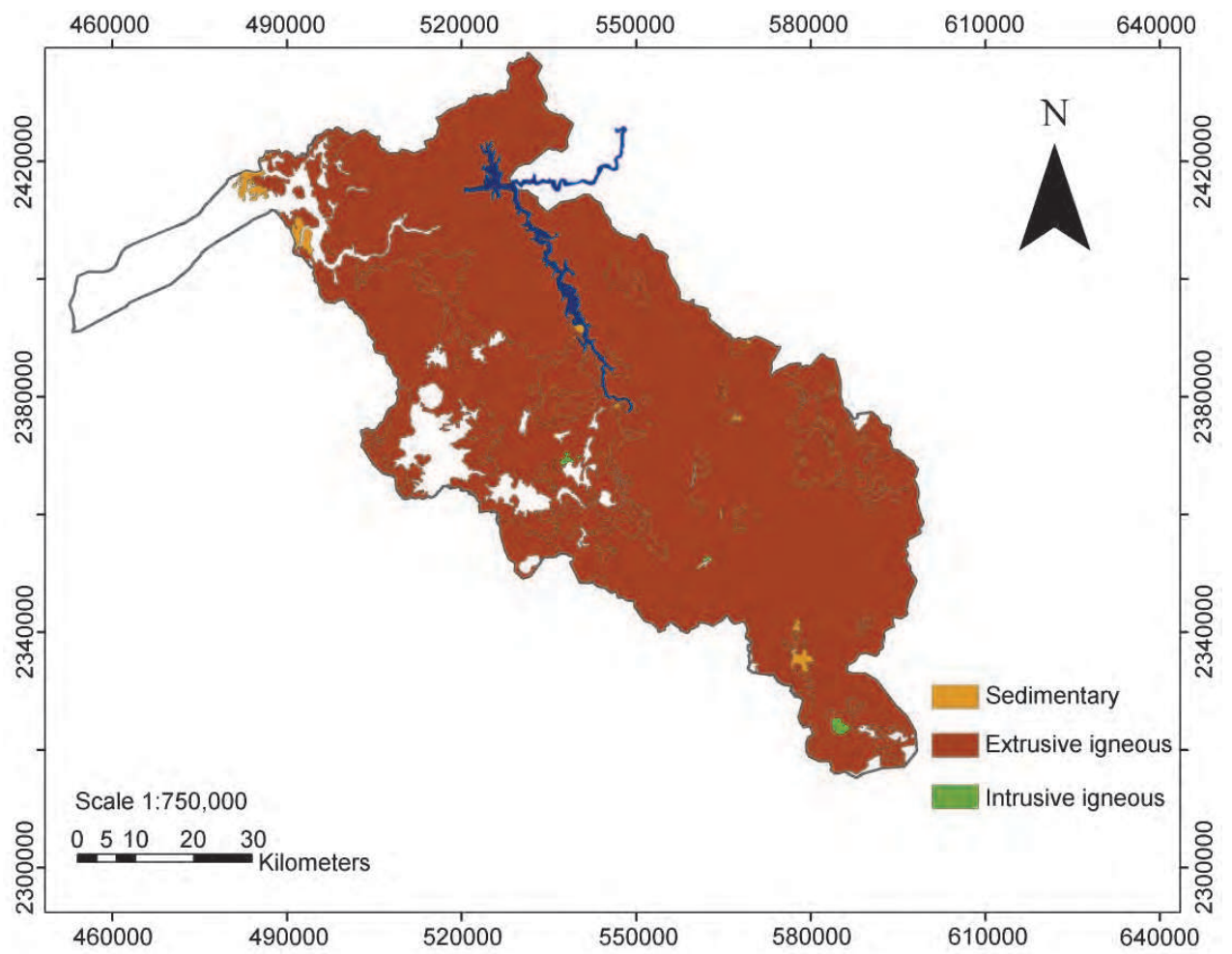

Fig. 2. Extrusive volcanic rocks distribution in the Santiago basin.

\section{Materials and methods}

All the aforementioned features were represented in a bathymetric map. This map represents an important tool for water quality modeling proposes due to it is highly relation to the reservoir hydrologic/hydrodynamic regime (Moses et al., 2011). Along with meteorological and hydrodynamic data and water quality parameters, it helps to determine the hydrodynamic behavior of the reservoir, improving the knowledge of vertical mixing processes, stratification and reaeration.

The development of a hydrodynamic and water quality model begins by creating the reservoir's bathymetry data. Getting a high-quality bathymetry is important to create an accurate model. The bathymetry of the Aguamilpa reservoir was created by using 1:50,000 scale Digital Elevation Models (DEMs), which were obtained from National Institute of Statistics, Geography and Informatics of Mexico (INEGI), and the Watershed Modeling System version 8.0 (WMS) software (Nelson, 2006). The necessary DEMs to cover the Aguamilpa reservoir were: F13D11, F13D12, F13D13, F13D21, F13D22, F13D23, F13D31, F13D32 and F13D33 according with the National Institute of Statistics, Geography and Informatics (INEGI, 2008). DEMs were available in the spatial resolution of 50x50 meter grids. 


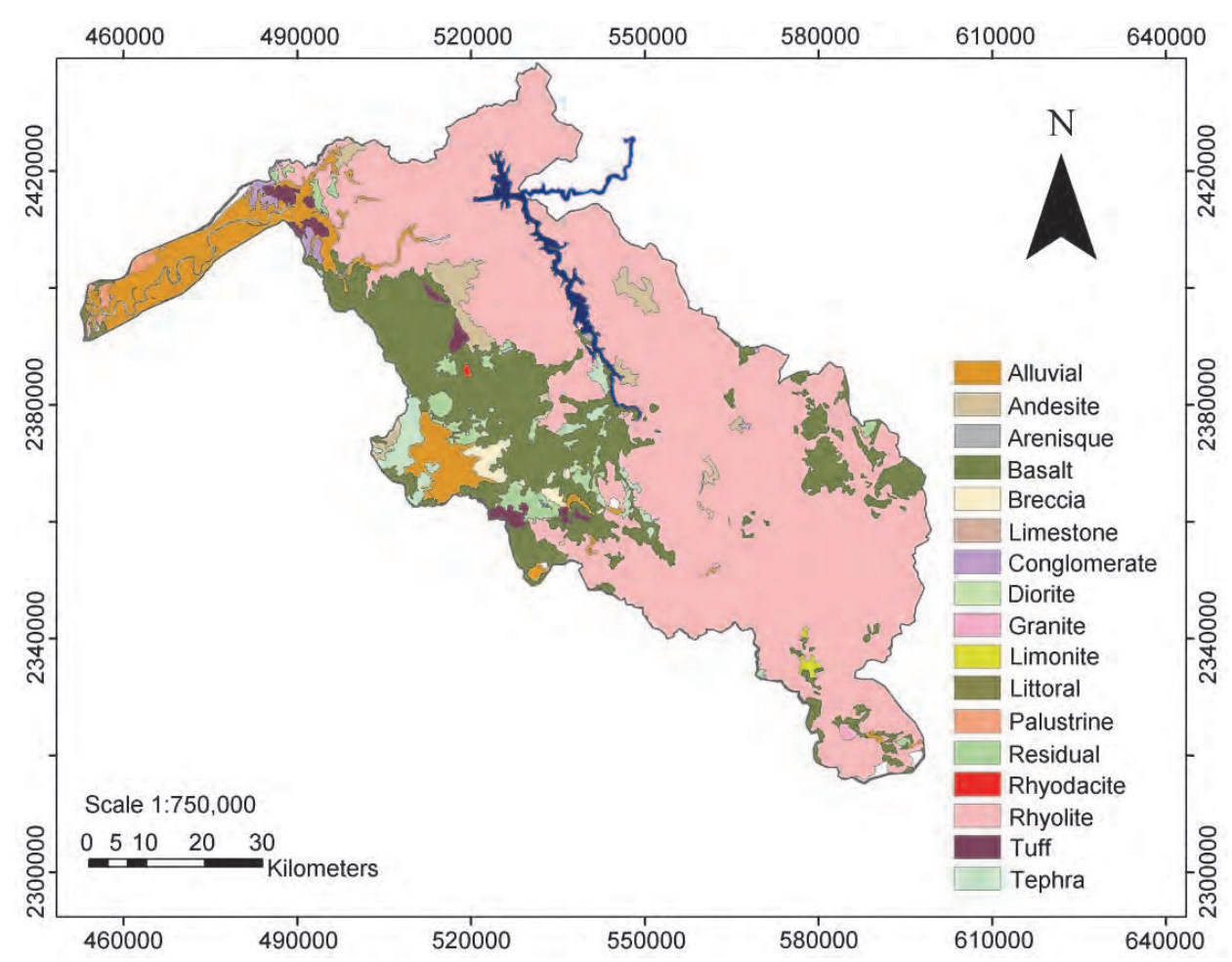

Fig. 3. Volcanic rock types distribution in the Santiago-Aguamilpa basin.

WMS is defined by Aquaveo (2011) as a comprehensive graphical modeling environment for all phases of watershed hydrology and hydraulics. WMS provides a variety of capabilities which include cross-section extraction from terrain data, watershed delineation, calculation of the geometry watershed and others. Similar to a Geographic Information System (GIS) format, spatial data was read into WMS and processed. DEMs were converted to Triangulated Irregular Networks (TINs) using WMS to define the boundaries and storage capacity of the Aguamilpa reservoir.

A pre-processor named W2i, included in the W2i-AGPM Modeling System User Interface for CE-QUAL-W2, is a powerful water quality modeling tool created and managed by Loginetics, Inc. (Hauser, 2007). W2i was used in several occasions to check the created bathymetry of the Aguamilpa reservoir. Viewing the bathymetry in W2i pre-processor allowed an improvement in the bathymetry created by WMS.

The resulting bathymetry was used to compute surface and volume curves. This information was then compared with the hypsographic curves provided by the Federal Electricity Commission (CFE, 2002) to validate the results obtained. Bathymetry accuracy was evaluated by the percentage error statistic. This statistic was calculated from the relative error which is the quotient between the absolute error and the reference value. The percentage error is $100 \%$ times the relative error. 


\section{Results and discussion}

WMS processed the DEM data to produce a bathymetry for Aguamilpa reservoir, which is compatible with some water quality models, such as CE-QUAL W2 (Obregon et al., 2011). DEMs were converted to Triangulated Irregular Networks (TINs) and the boundaries of the reservoir were defined (Figure 4).

The reservoir's boundaries were set at a maximum elevation of 235 meters (corresponding to the high-water level in the reservoir), resulting in an extension of the reservoir approximately $60 \mathrm{~km}$ along the Santiago River and $25 \mathrm{~km}$ along the Huaynamota River (Figure 5).

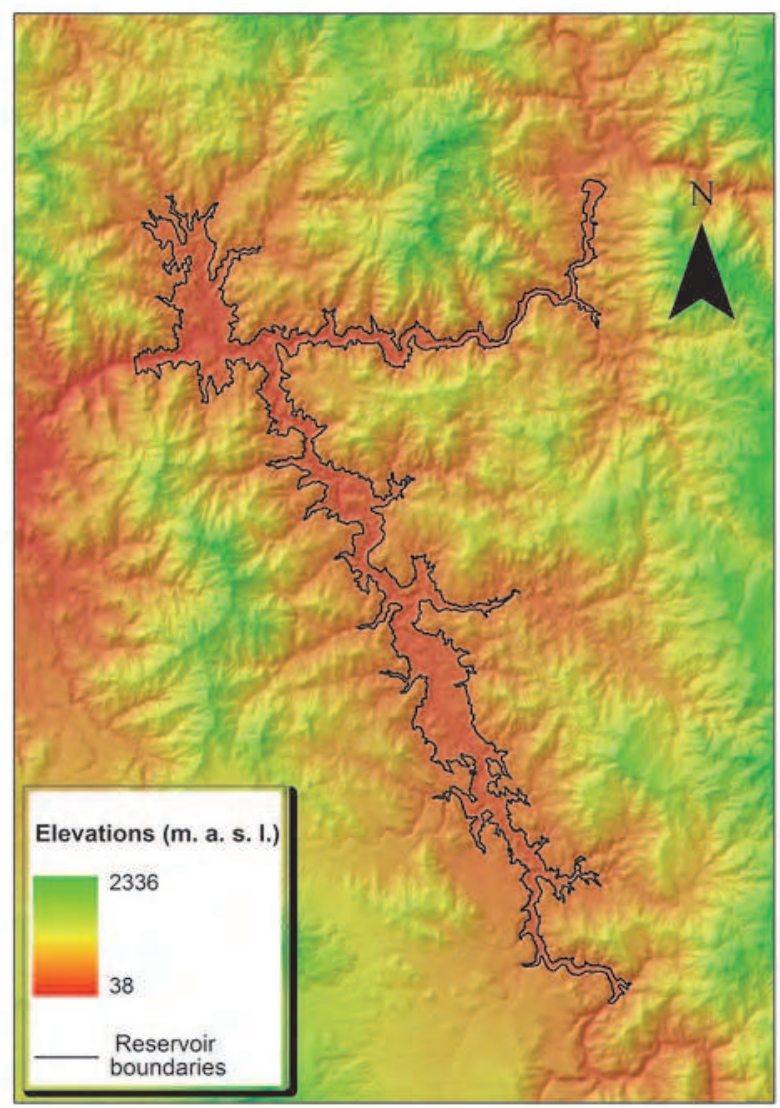

Fig. 4. DEM and boundaries of Aguamilpa reservoir.

Using this bathymetry, the Aguamilpa water body was discretized into a series of longitudinal segments. This was done by creating polygons longitudinally along the reservoir. After specifying a layer height of 1 meter for all cells, the cell widths were calculated from the TIN developed for Aguamilpa reservoir. The segments widths were calculated by using the length, depth and volume of the segments as following: 


$$
\text { Width }=\frac{\text { Volume }}{\text { Depth * Length }}
$$

According to this, Aguamilpa reservoir was divided into segments each roughly 500 meters long. At the beginning, WMS generated a maximum number of 155 layers with one meter thickness each. This situation was related to the minimum elevation of the used DEM's, which was 80 meters. However, 13 more layers were added by hand to the 155 generated layers (1 meter) to obtain 168 layers of a maximum number for each single segment.

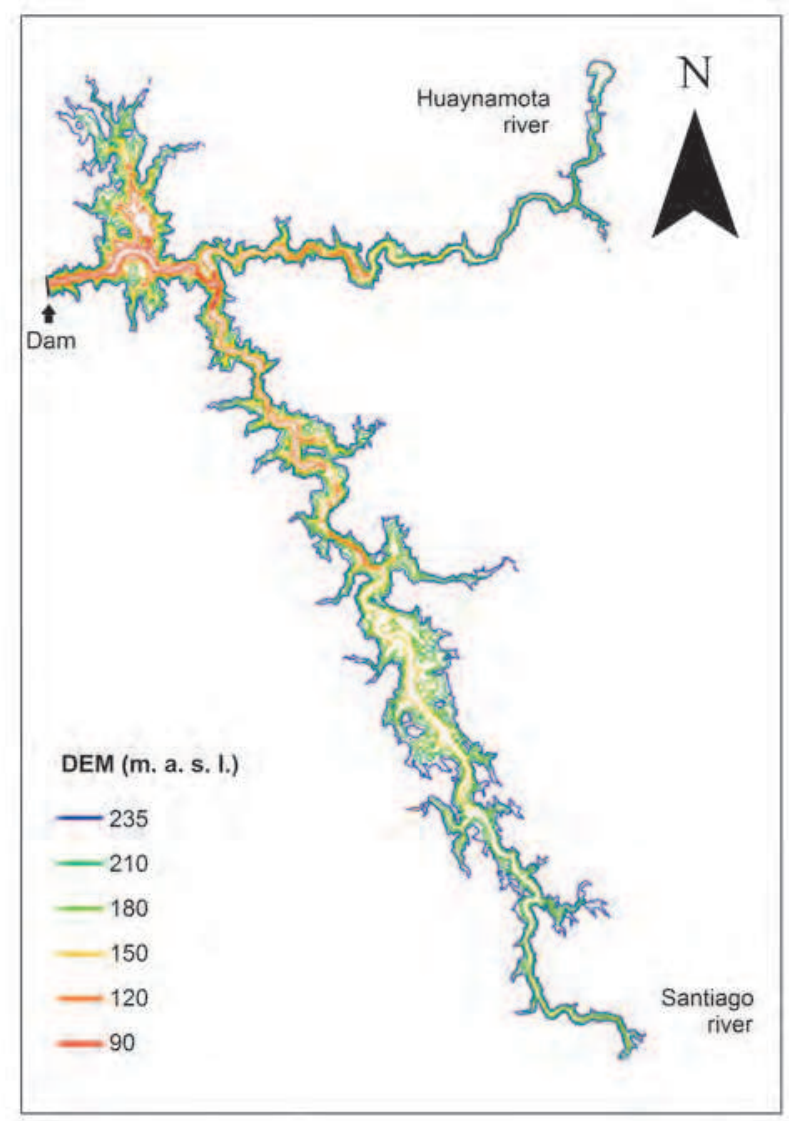

Fig. 5. Bathymetry of Aguamilpa reservoir.

This is because the maximum reservoir's depth is 187 meters not 155 meters. Another bathymetry study for Aguamilpa reservoir confirmed this information and reported that the minimum elevation is observed at 64.3 meters (GRUBA, 1997). The segment lengths and layer heights agree with those used by Ha and Lee (2007) in Daecheong Reservoir and Debele et al. (2006) in Cedar Creek Reservoir. This situation guarantees a sufficiently refined grid in the Aguamilpa bathymetry model. This is an example of an error in the bathymetry which could impact in the results of a hydrodynamic model of the reservoir and thus its calibration. 
The bathymetry of the Aguamilpa reservoir includes a total of 3 branches and 103 segments along the three tributary branches and a total of 168 layers in its deepest part. The three created branches are identified as: Branch 1 (Santiago River), Branch 2 (Huaynamota River) and Branch 3 (Ensenada) with Branch 1 being the largest and Branch 3 the shortest. The average segment length and width were 1,215 meters and 1,349 meters respectively.

The largest segment length was 1,724 meters and the maximum segment width was 3,032 meters. The shortest segment measures 487 meters and the narrowest segment measures 217 meters. The final bathymetry grid of the branch 1 (Santiago river) is presented in Figure 6, and the final bathymetry grid of branch 2 (Huaynamota river) is shown in Figure 7. These bathymetric profiles were depicted using W2i preprocessor.
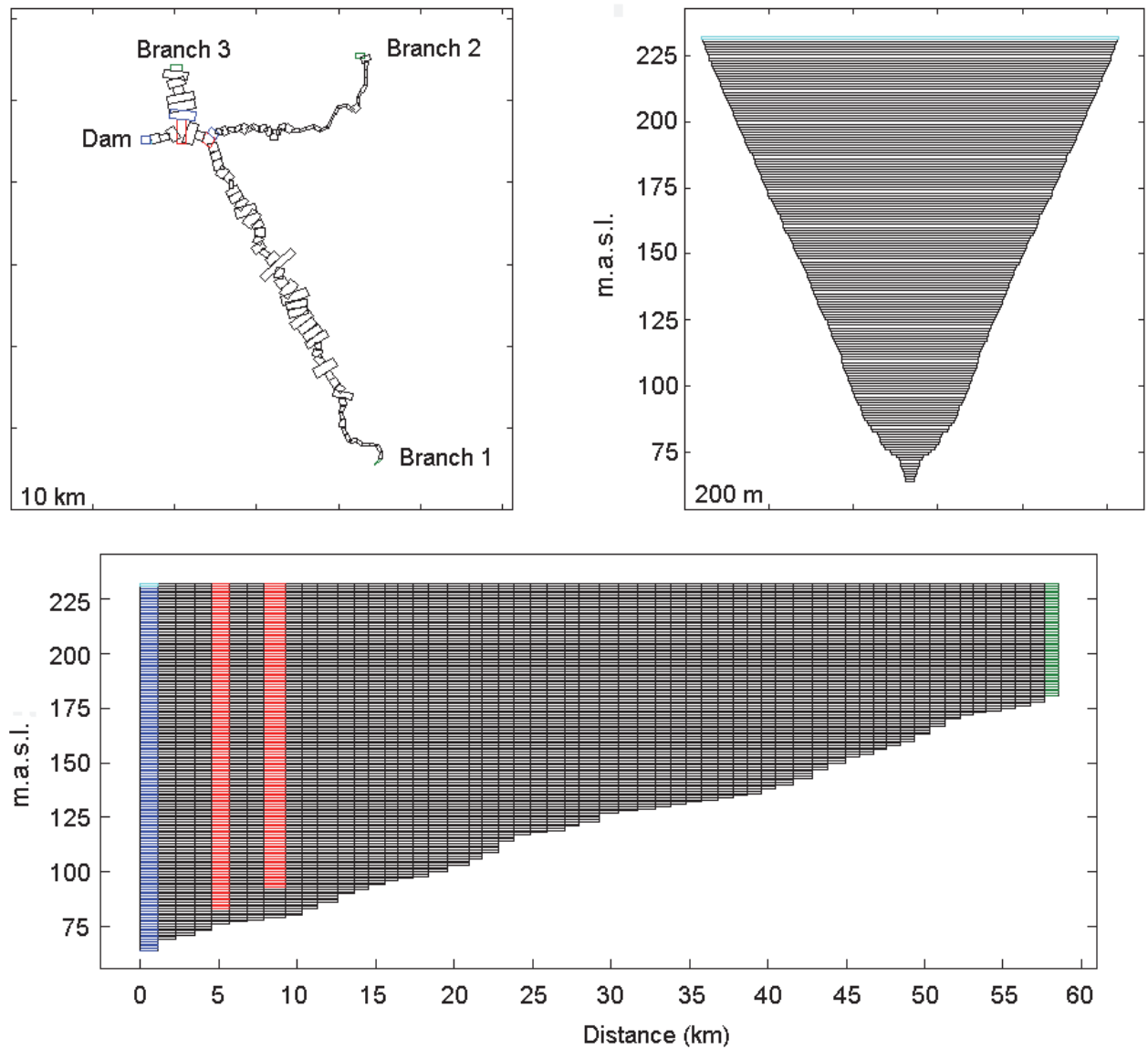

Fig. 6. Bathymety grid of Santiago river or Branch 1. This graphic illustrates the location of the aforementioned branch at the top left side and shows the cross-section of its deepest part at the top right side. The cross-section is then identified with a blue color in the horizontal profile of this branch at the bottom of this figure, where the red grids represent the connection between Branch 2 and 3 with Branch 1 and green grids correspond to the shallowest section of Santiago river. 
The Aguamilpa reservoir presents an extended and narrow shape, with a typical bathymetric profile of a river-dammed reservoir. The main tributary river of Aguamilpa reservoir is located about $55 \mathrm{~km}$ from the wall dam.
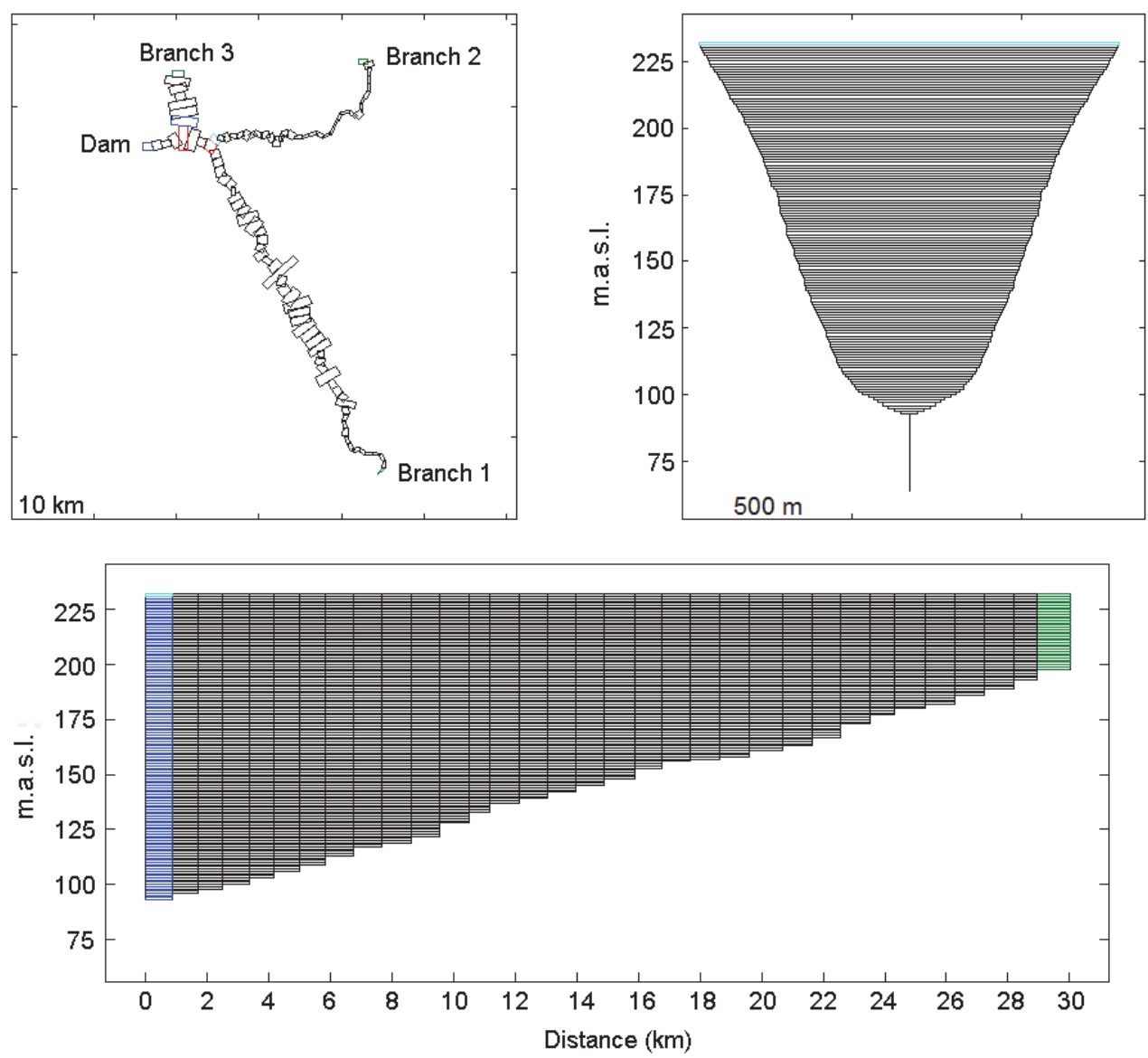

Fig. 7. Bathymetry grid of Huaynamota river or Branch 2. This graphic illustrates the location of the aforementioned branch at the top left side and shows the cross-section of its deepest part at the top right side. This cross-section is then identified with a blue color in the horizontal profile at the bottom of this figure, where the green grids correspond to the shallowest section of this river.

According to this information, it is possible to identify the presence of a longitudinal zonation in Aguamilpa reservoir: a riverine zone, a transitional zone and a lacustrine zone. The existence of these zones in the reservoir agrees with other reservoir bathymetry studies done by Margalef (1983), Wetzel (1993) and Comerma et al. (2003). This information can be used to understand some limnological conditions that could be associated to morphology in Aguamilpa reservoir. 
The main morphometric features of Aguamilpa reservoir were evaluated using the results obtained in the bathymetry. These features were estimated according to methodology suggested by Hutchinson (1957), Wetzel and Likens (2000) and Torres-Orozco (2007) and are shown in Table 1.

\begin{tabular}{|c|c|}
\hline Parameter $($ Units) & Value \\
\hline Total volume $\left(\mathrm{Mm}^{3}\right)$ & $6,933.4$ \\
\hline Surface area $\left(\mathrm{km}^{2}\right)$ & 109 \\
\hline Maximum lenght $(\mathrm{km})$ & 58 \\
\hline Maximum width $(\mathrm{m})$ & 4,952 \\
\hline Maximum depth $(\mathrm{m})$ & 164 \\
\hline Mean depth & 63 \\
\hline
\end{tabular}

Table 1. Morphometric features of Aguamilpa reservoir.

The maximum depth of Aguamilpa reservoir is much greater than its mean depth having a maximum depth to mean depth ratio of 3.74:1. These results demonstrate that a considerable proportion of the reservoir total volume is derived from relatively shallow areas which were created when the former riverine flood plain was permanently flooded.

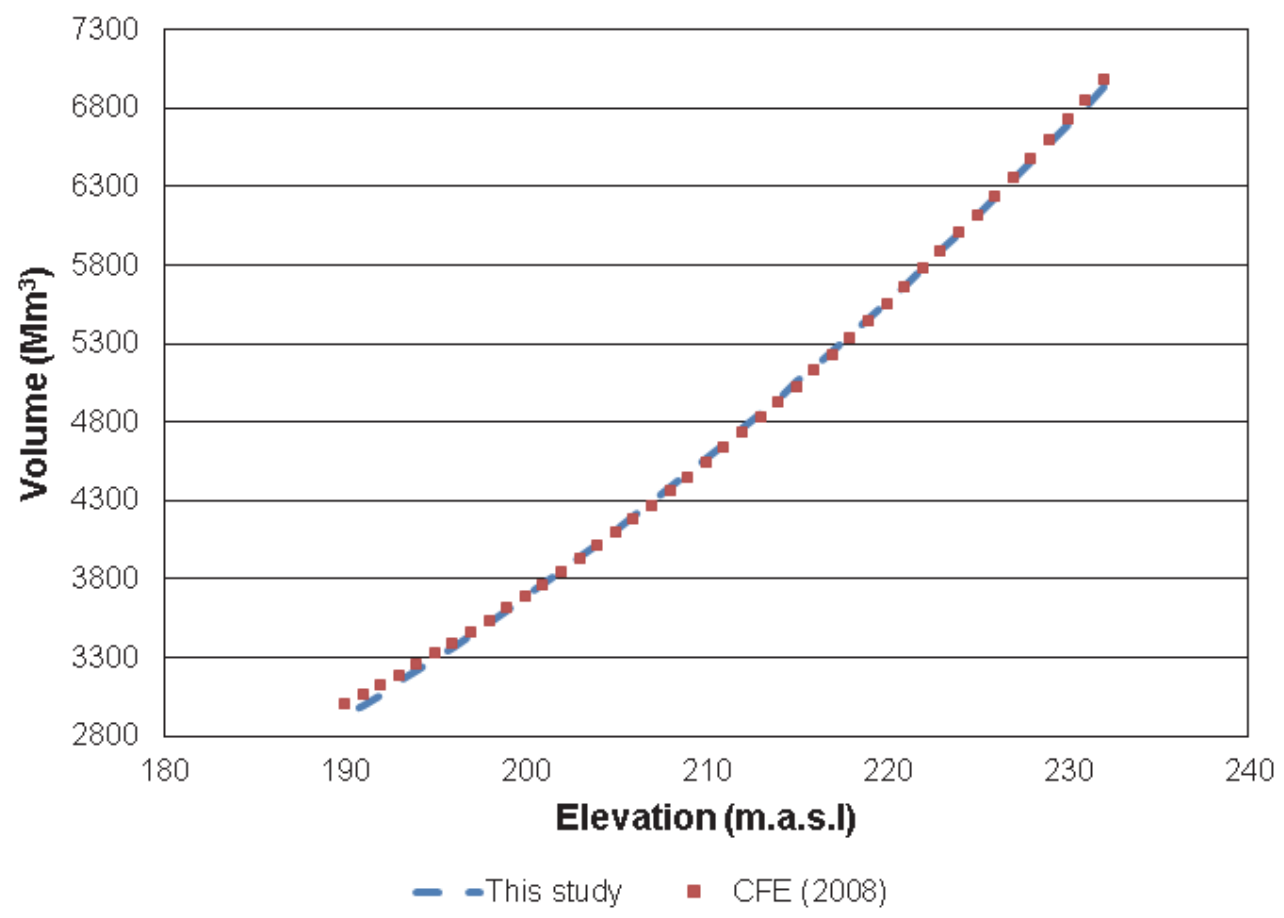

Fig. 8. This study's hypsographic curves. 
A storage capacity curve was then created from the bathymetry file and was compared with the storage capacity obtained from CFE obtained to check the accuracy of the bathymetry data. As shown in Figure 8, the created storage capacity curve was similar to the curve reported by $\mathrm{CFE}$.

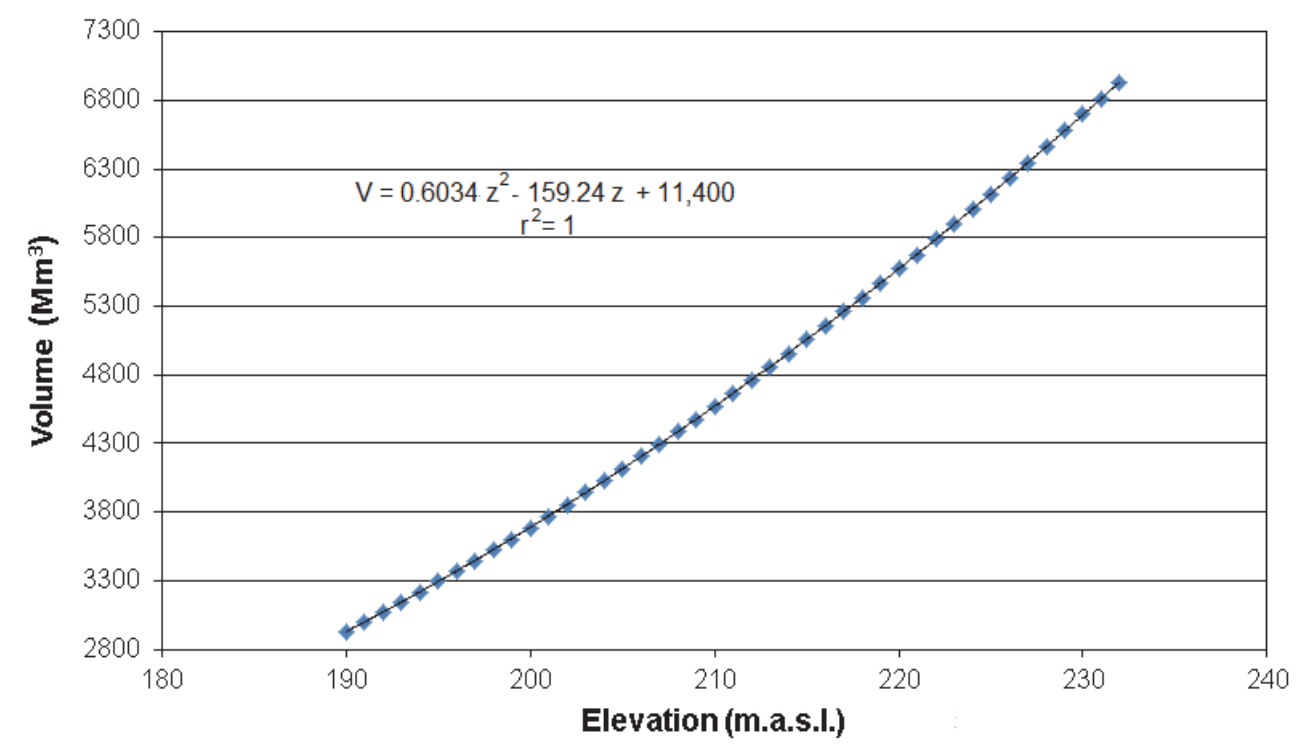

- Volume $\left(\mathrm{Mm}^{3}\right) \quad$ - Polynomial regression

Fig. 9. Reservoir volume-elevation polynomial regression.

This comparison showed that the DEM 1:50,000 available from INEGI (2008) and used for the present study was adequate to develop an accurate bathymetry for the Aguamilpa reservoir. This situation is also demonstrated with the low relative error showed in the model. The mean relative error between the official and present bathymetry was $0.3 \%$. Therefore, the use of DEMs simplified the process of bathymetry development for water quality modeling making forecasts based on the predetermined full supply level contour.

It is important not only to maintain the overall volume area capacity curve, but also to stay very close through each elevation zone. Since inflow will seek their own density level in the reservoir, hydrodynamic calibration can be altered by errors at critical elevations in volume and general shape of the bathymetry file. Temperature is usually the primary controller of this density placement with depth in the reservoir.

A regression was carried out on the bathymetric information relative to reservoir volume and elevation (Figure 9). The data was fitted by a second degree polynomial with the least squares method. The equation that best describes the volume-elevation ratio was:

$$
V=11,400-159.24 \mathrm{z}+0.6034 \mathrm{z}^{2}
$$




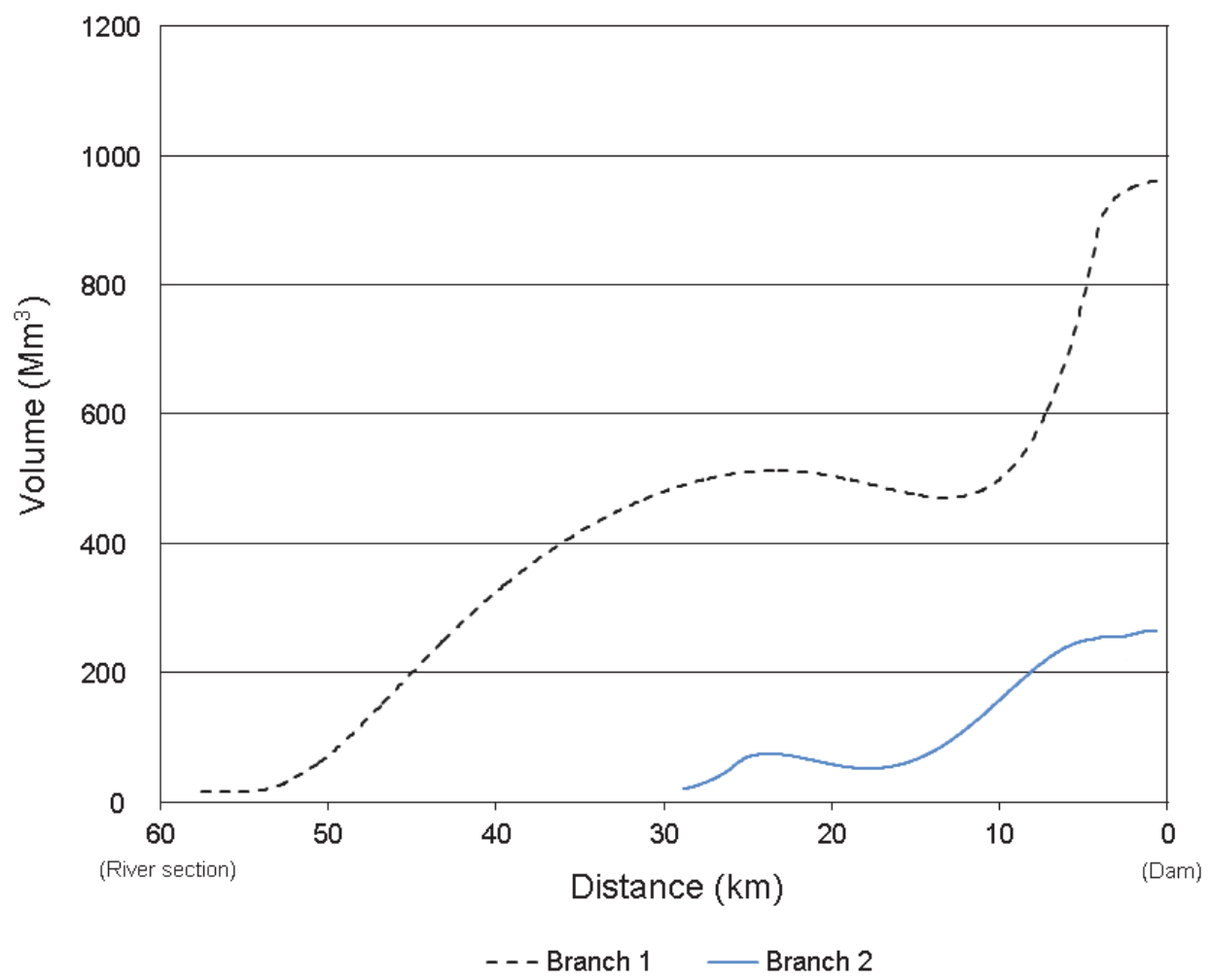

Fig. 10. Aguamilpa reservoir volume as a function of distance from the dam.

Where $V$ is the volume in $\mathrm{Mm}^{3}$ and $z$ is surface height in meters above sea level (m.a.s.l.). This ratio showed a high correlation coefficient $\left(r^{2}=1\right)$ for a water surface altitude range from 190 m.a.s.l. to 235 m.a.s.l, which are the operation levels of the Aguamilpa reservoir (minimum and maximum, respectively).

According to this equation, it is possible to compute reservoir volumes as a function of water elevation. This information is important for conservation and flood control of the reservoir. Storage capacity curves were also created for each branch and segment. These storage capacity curves show the storage of the reservoir at different locations (Figure 10).

\section{Conclusions}

A methodology was applied to demonstrate that a good resolution bathymetry can be developed by using DEM in one of the largest tropical reservoirs. A good agreement between the bathymetry computed in the present work and the hypsographic curves provided by CFE in the Aguamilpa reservoir was identified, with $0.3 \%$ of mean relative error.

Commonly scientist and engineers use the data obtained from sonar mounted beneath or over the side of a boat to make bathymetric maps. The use of WMS was advantageous because creating bathymetry for Aguamilpa reservoir took hours instead of weeks. WMS 
also allowed modification of the bathymetry to ensure that results were not adversely affected by grid resolution. However, if all the data must be collected using boats and sonar equipment, these surveys will still takes weeks to attain and this data collection is expensive.

The application of this methodology supports the use of DEMs for the development of reservoir bathymetries and may be applied to other reservoirs. The proposed tool would also increase stability and decrease run times in further water quality models. The use of WMS can also help quickly modify the bathymetry to simpler or more complex forms to determine if there is a critical point of complexity at which hydrodynamic results will be compromised. Ultimately using the simplest bathymetry that produces correct results can reduce model computation time.

\section{Acknowledgments}

The authors thank CFE for the provided elevation-capacity curve information and INEGI for their support in DEMs data. They are also thankful for the support provided by CONACYT Basic Science funds and the scholarship granted for the postgraduate studies of the first and second author.

\section{References}

Aquaveo. (2010). Watershed Modeling System, In: WMS 8.4 Tutorials - Volume 6, Accessed on January 15th 2011, Available from: http://wmstutorials.aquaveo.com/Tutor84 _Vol_VI.pdf.

Ceyhun, Ö. \& Yalçın, A. (2010). Remote sensing of water depths in shallow waters via artificial neural networks, Estuarine, Coastal and Shelf Science, 89, 89-96, ISSN: 02727714.

CFE. (1997). Proyecto Hidroelectrico Aguamilpa, Nayarit Mexico, Official report of Federal Commission of Electricity, Nayarit, Mexico, 36 p.

CFE. (2002). Informe Final de los Estudios Hidrologicos e Hidraulicos, Federal Commission of Electricity, Nayarit, Mexico, 40 p.

Comerma, M.; Garcia, J.C.; Romero, M.; Armengol, J. \& Simek, K. (2003). Carbon Flow Dynamics in the Pelagic Community of the Sau Reservoir (Catalonia NE Spain), Hydrobiologia, 504, 87-98, ISSN: 0018-8158.

Debele, B.; Srinivasan, R. \& Parlange, J.-Y. (2006). Coupling upland watershed and downstream waterbody hydrodynamic and water quality models (SWAT and CE QUAL-W2) for better water resources management in complex river basins, Environmental Modeling and Assessment Journal, 13,135-153, ISSN: 1420-2026.

GRUBA. (1997). Estudio de Calidad del Agua en el Embalse de la Presa Aguamilpa, Nayarit, National Commission of Water, Report Number GSCA 007/97, Nayarit, Mexico, $109 \mathrm{p}$.

Ha, S.-R. \& Lee, J.-Y. (2007). Application of CE-QUAL W2 Model to Eutrophication Simulation in Daecheong Reservoir Stratified by Turbidity Storms, Proceedings of Taal 2007-The 12th World Lake Conference, pp. 824-833, Jaipur, India, 29th Oct - 2th Nov, 2007.

Hutchinson, G.E. (Ed.) (1957). A treatise on limnology. Volume I: Geography, Physics and Chemistry, John Wiley, ISBN: 9780471425700, New York, USA. 1015 p. 
Hauser, G. (2007). Loginetics AGMP, CE-QUAL-W2 model post processor. In: Thermal and Bioenergetics Modeling for Balancing Energy and Environment, Accessed on August 30th, 2010, Available from http://www.loginetics.com/pubsm/Modeling.html.

Ibarra-Montoya, J.L., Rangel-Peraza, G., González-Farías, F.A., de Anda, J., Zamudio-Reséndiz, M.E., Martínez-Meyer, E. \& Macias-Cuellar, H. (2010). Modelo de nicho ecológico para predecir la distribución potencial de fitoplancton en la Presa Hidroeléctrica Aguamilpa, Nayarit. México. Ambi-Agua. 5(3), 60-75, ISSN: 1980-993X.

INEGI. (2005). Anuario Estadístico del Estado de Nayarit. Edición 2005. National Institute of Statistics, Geography and Informatics of Mexico y Nayarit State Government. Nayarit, Mexico. 580 p.

INEGI. (2008). Sistema de Descarga del Continuo de Elevaciones Mexicano, In: Sistema Nacional de Informacion Estadistica y Geografica. Accessed on January 28th, 2011 Available from:

http:/ / mapserver.inegi.org.mx/DescargaMDEWeb/?s=geo\&c=977

Manivanan, R. (2008). Water quality modelling: basics, In: Water Quality Modeling. Rivers, Streams and Estuaries, R. Manivanan (Eds), pp. 15-28, New India Publishing Agency, ISBN: 1397889422936, New Delhi, India.

Margalef, R. (1983). Limnologia. Eds. Omega, ISBN: 9788428207140, Barcelona, Spain, 1024 p

Mendes, F. (1995) Aguamilpa underground penstocks - excavation phase, International Journal of Rock Mechanics and Mining Sciences and Geomechanics Abstracts, 32(4), 188188, ISSN 0148-9062

Mendes, F. (2005). Rapid construction of the El Cajon CFRD, Mexico. International Journal on Hydropower and Dams. 12(1), 67-71, ISSN 1352-2523.

Miller, F. P., Vandome, A. F., McBrewster, J. (2010). Bathymetry. VDM Publishing House Ltd., 2010 -68 p. ISBN: 6130704542.

Moses, S.A., Janaki, L., Joseph, S., Justus, J., Vimala, S.R. (2011). Influence of lake morphology on water quality, Environ. Monit. Assess., In press, ISSN: 0167-6369.

Nelson, E.J. (2006). CE-QUAL-W2 Interface, In: WMS v8.0 Tutorials. Accessed on February 23th, 2011, Available from: http://www.cequalw2wiki.com/cequalw2/images/ 9/99/WMS_8.0_CE-QUAL-W2_Tutorial.pdf

Obregon, O., Chilton, R.E., Williams, G.P., Nelson, E.J., Miller, J.B. (2011). Assessing Climate Change Effects in Tropical and Temperate Reservoirs by Modeling Water Quality Scenarios, Proceedings of the 2011 World Environmental and Water Resources Congress, paper 407, Palm Springs, USA, ISBN: 978-0-7844-1173-5.

Rangel-Peraza, J.G., de Anda, J., González-Farías, F.A. \& Erickson, D.E. (2009). Statistical assessment of water quality seasonality in large tropical reservoirs, Lakes $\mathcal{E}$ Reservoirs: Research and Management, 14(4), 315-323, ISSN: 1440-1770.

Torres-Orozco, R.E. (2007). Batimetria y morfometria, In: Limnologia de las presas mexicanas. Aspectos teoricos y practicos, J.L. Arredondo-Figueroa, G. Diaz-Zabaleta and J.T. Ponce- Palafox (Eds), pp. 3-19, AGT Editor S.A., Mexico, D.F. ISBN: 9789684631366.

Wetzel, R.G. (1993) Limnologia. Fundacao Calouste Gulbenkian. Lisboa, Portugal, 919 p. ISBN: 9789723106046.

Wetzel, R.G., Linkens, G.E. (2000). Limnological analyses. Springer. NewYork, USA, 429 p. ISBN. 0387989285.

Xu, X., Tan, Y., Yang, G., Li, H., Su, W. (2011) Soil erosion in the Three Gorges Reservoir area. Soil Research. 49, 212-222. ISSN: 1838-6768.

Zhao, X., Shen, Z.Y., Xiong, M., Qi, J. (2011) Key uncertainty sources analysis of water quality model using the first order error method. Int. J. Environ. Sci. Tech. 8 (1), 137148. ISSN: 1735-1472. 


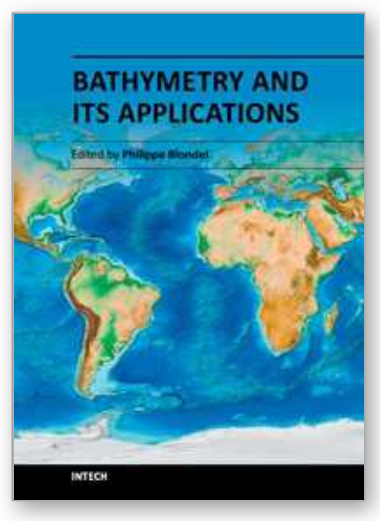

\author{
Bathymetry and Its Applications \\ Edited by Dr. Philippe Blondel
}

ISBN 978-953-307-959-2

Hard cover, 148 pages

Publisher InTech

Published online 25, January, 2012

Published in print edition January, 2012

Bathymetry is the only way to explore, measure and manage the large portion of the Earth covered with water. This book, presents some of the latest developments in bathymetry, using acoustic, electromagnetic and radar sensors, and in its applications, from gas seeps, pockmarks and cold-water coral reefs on the seabed to large water reservoirs and palynology. The book consists of contributions from internationally-known scientists from India, Australia, Malaysia, Norway, Mexico, USA, Germany, and Brazil, and shows applications around the world and in a wide variety of settings.

\title{
How to reference
}

In order to correctly reference this scholarly work, feel free to copy and paste the following:

José de Anda, Jesus Gabriel Rangel-Peraza, Oliver Obregon, James Nelson, Gustavious P. Williams, Yazmín Jarquín-Javier, Jerry Miller and Michael Rode (2012). The Use of Digital Elevation Models (DEMs) for Bathymetry Development in Large Tropical Reservoirs, Bathymetry and Its Applications, Dr. Philippe Blondel (Ed.), ISBN: 978-953-307-959-2, InTech, Available from: http://www.intechopen.com/books/bathymetry-andits-applications/the-use-of-digital-elevation-models-dem-for-bathymetry-development-in-large-tropicalreservoirs

\section{INTECH}

open science | open minds

\section{InTech Europe}

University Campus STeP Ri

Slavka Krautzeka 83/A

51000 Rijeka, Croatia

Phone: +385 (51) 770447

Fax: +385 (51) 686166

www.intechopen.com

\section{InTech China}

Unit 405, Office Block, Hotel Equatorial Shanghai

No.65, Yan An Road (West), Shanghai, 200040, China

中国上海市延安西路65号上海国际贵都大饭店办公楼405单元

Phone: +86-21-62489820

Fax: +86-21-62489821 
(C) 2012 The Author(s). Licensee IntechOpen. This is an open access article distributed under the terms of the Creative Commons Attribution 3.0 License, which permits unrestricted use, distribution, and reproduction in any medium, provided the original work is properly cited. 